\title{
UJI PERKEMBANGBIAKAN VEGETATIF SINTOK (Cinnamomun sintoc Blume.) DENGAN PERLAKUAN HORMON DAN MEDIA TUMBUH
}

\author{
Nanang Hanafi dan Nurul Hidayati \\ Fakultas Pertanian dan Kehutanan, Universitas Muhmamadiyah Palangkaraya \\ Email :nananghanafi@gmail.com; hidayatiump@gmail.com
}

\begin{abstract}
Sintok (Cinnamomum sintoc Blume) including medicinal plants that are widely used by the community (components of herbal medicine and traditional medicine). It categorizes as a plant producing essential oils concerning Non-Timber Forest Products (NTFPs). The existence in nature is begin to erode, because of logging to take the bark. Sintok seeds include recalcitrant, and trees rarely bear fruit. Research objectives (1) to find out whether Sintok can be developed by vegetative I cuttings, (2) to determine the success of the growth of shoots of sintok by media and hormone treatment. The experimental design used in this study was a Split Plot. The main plot was a type of media consisting of three levels MO (soil / control), M1 (land with 2: 1 husk charcoal), M2 (soil, sand, with 1: 1: 1 husk charcoal) and as subplots is was the administration of a type of root stimulant or hormone, consisting of three levels, namely P0: No root stimulant (control), P1 (Rootone-F), P2 (Coconut Water). The results showed that Sintok could be cultured by cuttings and, developed with stem / shoot cuttings. The observations of 8 weeks after planted cuttings that were still alive an average of $15.43 \%$ and MOPO treatment resulted in live cuttings of 55.55\%. The average cuttings sprouted at 8 weeks after planted observations was $2 \%$. The sprout cuttings, all root still does not appear.
\end{abstract}

Keyword: Sintoc (Cinnamomum sintoc Blume), cuttings, hormons and growth media

\section{PENDAHULUAN}

Indonesia memiliki berbagai jenis tumbuhan obat dari berbagai tipe ekosistem hutan yang berhasil diidentifikasi dan diinvetarisasi tidak kurang dari 1845 jenis (Zuhud, 1997 dalam Arifin et al. 2011). Penggunaan tumbuhan obat yang ada di hutan merupakan salah satu manfaat dari nilai hutan itu sendiri. Salah satu tumbuhan obat yang banyak digunakan masyarakat adalah tumbuhan sintok (Cinnamomum sintoc Blume). Sintok merupakan suku Lauraceae yang termasuk dalam katagori langka. Selain diketahui untuk tumbuhan obat, sintok juga ditetapkan sebagai jenis tumbuhan penghasil minyak atsiri berdasarkan Peraturan Menteri Kehutanan No.
P.35/Menhut-II/2007 tentang Hasil Hutan Bukan Kayu (HHBK).

Tumbuhan sintok dapat hidup hutan campuran dipterocarpaceae dan hutan dataran tinggi, terutama daerah berpasir. Sintok merupakan salah satu jenis tumbuhan penghasil minyak atsiri yang terdapat pada daun dan kayu. Tumbuhan sintok telah lama digunakan sebagai salah satu komponen jamu dan obat tradisional. Kulit batang sintok digunakan pengobatan diare atau gangguan pencernaan dan sebagai disinfektan dalam bentuk bubuk. Mengingat keberadaannya di alam sulit ditemukan, ditambah lagi ketidaktahuan masyarakat mengenai potensi dan ditebang untuk diambil kayunya. Hal ini menambah 
status kelangkaannya. Sehingga perlu dilakukan upaya pemanfaatan yang seiring dengan upaya pelestariannya. Perbanyakan sintok umumnya menggunakan benih yang tersedia di alam. Tetapi hal ini menjadi kendala, karena bijinya bersifat rekalsitran sehingga tidak dapat bertahan lama apabila tersebar secara alami di alam. Hal ini terbukti tidak terdapat anakan/seedling sintok yang berada dibawah pohon induknya.

Perkembangbiakan vegetatif dengan cara stek adalah salah satu cara untuk memperbanyak tumbuhan tanpa menggunakan biji. Teknik vegetatif dikembangkan untuk memecahkan masalah pembibitan untuk tanaman yang sukar dibudidaya melalui generatif (biji). Perbanyakan vegetatif tumbuhan sintok belum banyak dilakukan, hal ini kemungkinan disebabkan karena nilai ekonomis sintok yang masih rendah. Tujuan penelitian ini untuk (1) untuk mengetahui apakah Sintok dapat dikembangkan dengan cara vegetative/stek, (2) Mengetahui keberhasilan pertumbuhan stek pucuk sintok dengan perlakuan media dan zat pengatur tumbuh terbaik untuk perakaran stek sintok.

\section{METODE PENELITIAN}

\section{Waktu Penelitian dan Lokasi}

Penelitian ini dilaksanakan selama \pm 6 bulan, lokasi pengambilan stek pucuk sintok di KHDTK Mungku Baru/Hutan Pendidikan UM Palangkaraya Kecamatan Rakumpit Kota Palangka Raya; pemeliharaan dan pengamatan serta analisis data dilakukan di Jl. Manjuhan Cilik Riwut KM 5 Palangkaraya.

\section{Alat dan Bahan Penelitian}

Alat yang digunakan dalam penelitian ini adalah : GPS untuk menentukan kordinat lokasi, polybag, paranet, alat penyiram, gunting stek, plastik bening, box plastik untuk pengangkutan bahan stek sintok, penggaris, kamera.

Bahan yang digunakan : bahan stek sintok dari alam, batang pisang, alkohol 70\%, air kelapa murni, Rootone-F, topsoil, arang sekam, dan pasir

\section{Prosedur Penelitian}

Pelaksanaan penelitian ini terdiri dari beberapa tahapan, yaitu persiapan bibit dan media, pengangkutan, persiapan bahan stek, pemberian rootone-F dan perendaman air kelapa, penanaman, pemeliharan, pengamatan, pengambilan data, analisis data dan penyusunan laporan.

\section{a. Persiapan bahan stek dan media}

\section{tanam}

Persiapan bahan stek/vegetatif dilakukan di Hutan Pendidikan UM Palangkaraya, dengan cara survey lokasi untuk mendapatkan tumbuhan sintok. Setelah didapatkan tumbuhan sintok kemudian dilakukan pemotongan batang bagian pucuk untuk kemudian dikumpulkan dalam box plastik yang ada batang pisang. Pengambilan bahan stek dilakukan pada pukul 07.00-09.00 WIB

Media yang digunakan pada penilitian ini yaitu tanah, tanah dengan arang sekam (2:1), 
serta tanah, pasir dengan arang sek am (1:1:1). Masing-masing media tersebut disterilisasi dengan cara disangrai di atas seng rata yang dipanaskan dengan kompor gas selama 3 jam, dibalik-balik. kemudian didinginkan atau diaklimatisasi selama 24 jam. Setelah itu digunakan sesuai perlakuan media dan dimasukkan ke dalam box plastik sesuai perlakuan.

\section{b. Persiapan bahan stek}

Bahan stek dipotong dengan panjang 10-15 $\mathrm{cm}$, di pisahkan antara bagian pucuk, tengah dan bawah. Bagian pangkal dahan stek dipotong miring $45^{0}$ tepat di bawah buku, agar luas permukaan lebih besar. Kemudian bahan stek dimasukkan kedalam wadah berisi air agar tidak cepat layu.

\section{c. Pemberian zat pengatur tumbuh}

Pemberian Rootone-F dilakukan dengan cara mengoles ujung bawah bahan stek dengan Rootone-F yang sudah dijadikan pasta. Setelah diolesi, bahan stek dibalik (posisi ujung stek yang sudah diberi hormon di bagian atas) selama 5 menit. Hal tersebut dilakukan karena hormon perangsang yang digunakan mempunyai sifat translokasi dari atas ke bawah. Sedangkan pemberian air kelapa dilakukan dengan perendaman bagian pangkal stek selama 1 jam. Perlakuan kontrol dengan cara direndam dengan air biasa selama 15 menit kemudian langsung ditanam.

\section{d. Penanaman}

Penanaman stek dilakukan pada pagi hari. Stek ditanam pada media tanam dalam box plastik yang sudah sesuai dengan perlakuan. Media dilubangi terlebih dahulu mencapai kedalaman $3.5 \mathrm{~cm}$ sebelum dilakukan penanaman untuk menghindari pelukaan bahan stek khususnya bagian pangkal. Setelah stek ditanam, lubang dirapatkan kembali agar stek dapat tertanam dengan baik dan berdiri tegak. Kemudian setelah bahan stek ditanam, box plastik ditutup dengan plastik bening (disungkup). Setiap satu satuan percobaan terdapat 10 stek tanaman.

\section{e. Pemeliharaan}

Pemeliharaan dilakukan berkala dengan membuka sungkup plastik pada pagi hari satu jam dari jam 06.00 - 07.00 WIB setelah 14 hari setelah tanam stek. Penyemprotan Dithane M45 dilakukan untuk mengantisipasi terserangnya jamur pada stek.

\section{f. Pengamatan dan pengambilan data}

Variabel yang diamati yaitu persentase hidup stek, persentase bertunas, persentase stek berakar, panjang akar, dan jumlah akar.

Persentase hidup stek yaitu dengan menghitung jumlah stek yang mati dibandingkan dengan jumlah seluruh stek yang diamati. Rumus yang digunakan adalah :

Persentase hidup $=$

$\frac{\sum \text { Stek yang hidup }}{\sum \text { Keseluruhan stek diamati }} \times 100 \%$

Persentase tunas yaitu dengan menghitung jumlah stek yang bertunas dibandingkan dengan jumlah seluruh stek yang diamati. Rumus yang digunakan adalah : 
Persentase bertunas $=$

$\frac{\sum \text { Stek yang bertunas }}{\sum \text { Keseluruhan stek diamati }} \times 100 \%$

Persentase stek berakar dihitung selama dua kali pada minggu ke 2 dan ke 4 dengan menghitung jumlah stek hidup yang berakar dibandingkan dengan jumlah total stek secara keseluruhan, yaitu dengan rumus:

Persentase berakar $=$ $\frac{\sum \text { Stek yang berakar }}{\sum \text { Keseluruhan stek diamati }} \times 100 \%$

Panjang akar, dihitung dengan cara mengambil sampel stek pada masing-masing perlakuan disetiap ulangan, kemudian masingmasing akar stek yang tumbuh diukur mulai pangkal sampai titik ujung akar dengan menggunakan penggaris, selanjutnya dirataratakan dengan jumlah akar yang mucul pada stek.

Jumlah akar, dihitung dengan menjumlahkan akar tiap bahan stek hingga didapatkan jumlah akar total per ulangan dalam perlakuan. Akar yang dihitung adalah akar primer dan sekunder yang keluar dari permukaan batang bawah bahan stek minimal 1 buah dan panjang minimal $0.2 \mathrm{~cm}$. Pengukuran dilakukan dua kali pada minggu ke 2 dan akhir penelitian.

\section{g. Rancangan Percobaan}

Rancangan percobaan yang digunakan dalam penelitian ini adalah Petak Terbagi (Split Plot). Petak utama (main plot) adalah jenis media yang terdiri tiga taraf dan faktor pemberian jenis zat perangsang akar atau hormon sebagai anak petak (sub plot), yang terdiri dari tiga taraf.

Petak Utama $(\mathrm{M})$ = Jenis Media, yang terdiri atas: $\mathrm{M} 0=$ Tanah (kontrol), M1 = Tanah dengan arang sekam (2:1), M2 = Tanah, pasir, dengan arang sekam (1:1:1)

Anak Petak $(\mathrm{P})$ = Perangsang Akar, yang terdiri atas: $\mathrm{P} 0=$ Tanpa perangsang akar $($ kontrol $), \mathrm{P} 1=$ Rootone-F, $\mathrm{P} 2=$ Air Kelapa . Setiap satu satuan percobaan terdapat 10 stek tanaman.

Data yang diperoleh dianalisis dengan menggunakan analisis sidik ragam atau Uji $F$ pada taraf $\alpha=5 \%$ untuk mengetahui pengaruh perlakuan, Apabila terdapat pengaruh nyata dari perlakuan yang diberikan, maka dilanjutkan dengan uji Beda Nyata Terkecil (BNT) pada taraf 5\% (Steel \& Torrie 1993; Mattjik \& Sumertajaya 2006).

\section{HASIL DAN PEMBAHASAN}

\section{A. Hasil Penelitian}

\section{Persentase Stek Hidup}

Dari hasil penelitian yang telah dilakukan pada pengamatan 8 MST diketahui bahwa perlakuan media dan hormon tumbuh perpengaruh nyata terhadap persentase stek tumbuh. Rata-rata persentase stek hidup umur 8 MST dapat dilihat pada Tabel 1 dan Grafik 1.

Dari Tabel 1 menunjukkan bahwa perlakuan MOP0 menghasilkan persentase stek hidup yang paling tinggi yaitu 55\%, tetapi tidak berbeda nyata dengan perlakuan M0P2 (50\%). Perlakuan M1P0 tidak menghasilkan stek yang hidup. 


\section{Persentase Stek Bertunas}

Hasil pengamatan untuk variabel stek bertunas rendah pada 8 MST yaitu hanya 5,56\% pada perlakuan M0P1, M0P2, M1P1 dan M2P2, dapat dilihat pada Grafik 2.

Tabel 1. Rata-rata persentase hidup stek sintok umur 8 MST

\begin{tabular}{|l|r|}
\hline Perlakuan & Nilai Tengah \\
\hline & \\
\hline MOP0 & $55,55 \mathrm{~d}$ \\
\hline MOP1 & $38,89 \mathrm{bc}$ \\
\hline MOP2 & $50,00 \mathrm{~cd}$ \\
\hline M1P0 & $0,00 \mathrm{a}$ \\
\hline M1P1 & $16,67 \mathrm{ab}$ \\
\hline M1P2 & $11,11 \mathrm{ab}$ \\
\hline M2P0 & $16,67 \mathrm{ab}$ \\
\hline M2P1 & $16,67 \mathrm{ab}$ \\
\hline M2P2 & $22,22 \mathrm{abc}$ \\
\hline BNT 5 \% & 27,96 \\
\hline
\end{tabular}

Keterangan : Angka-angka yang didampingi notasi yang sama pada kolom yang sama tidak berbeda nyata pada uji BNT $5 \%$.

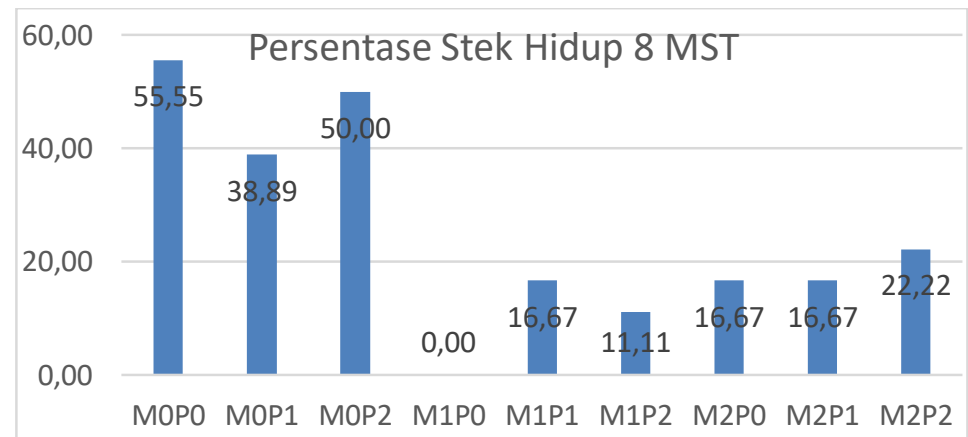

Grafik 1. Persentase stek hidup umur 8 MST

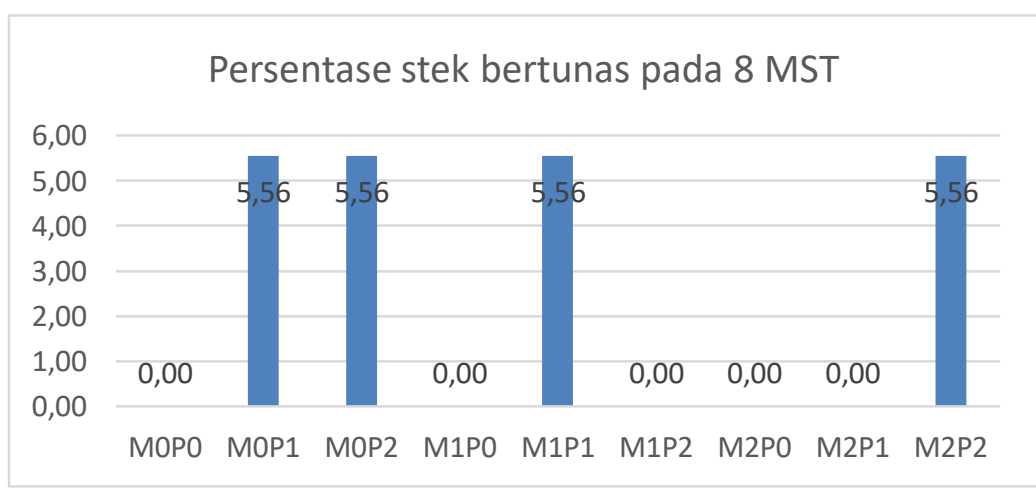

Grafik 2. Persentase stek bertunas pada pengamatan 8 MST 

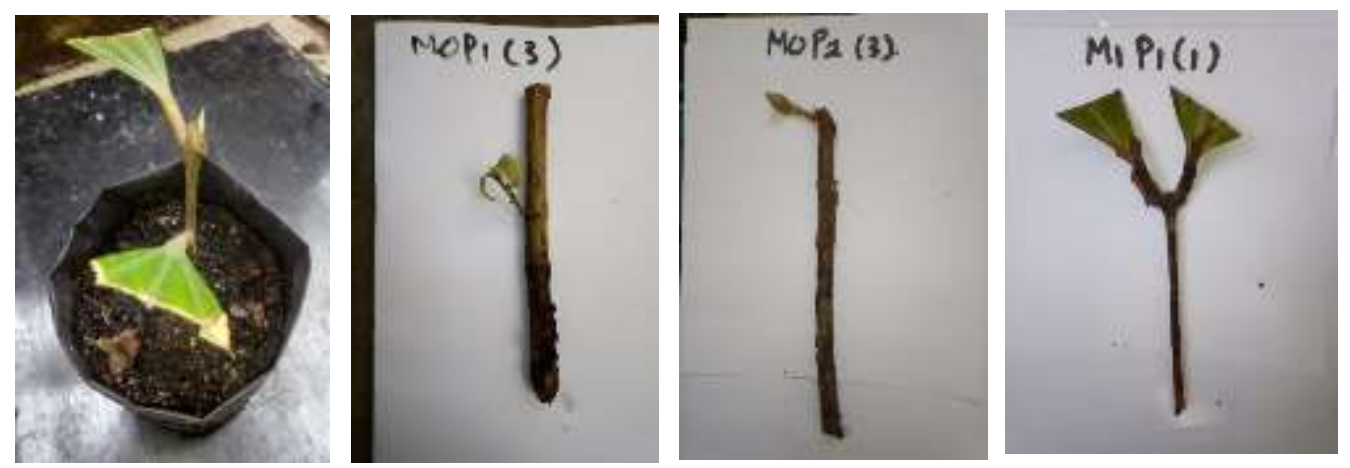

Gambar 1. Stek tanaman sintok belum muncul akar umur 8 MST

Hal tersebut menyebabkan tidak dapat dilakukan uji secara statistik.

\section{Persentase munculnya akar}

Pada pengamatan 8 MST dilakukan pencabutan stek, stek tanaman yang menghasilkan tunas maupun luka tertutup kallus kita amati keseluruhannya. Hasilnya tidak ada stek yang menghasilkan akar. Selengkapnya dapat dilihat pada Gambar 1.

\section{B. Pembahasan}

Rendahnya keberhasilan stek tanaman sintok dan pertumbuhan stek dipengaruhi oleh interaksi faktor genetik dan faktor lingkungan (Hartmann et al., 1997). Faktor genetik terutama meliputi kandungan cadangan makanan dalam bahan stek, ketersediaan air, umur tanaman (pohon induk), hormon endogen dalam bahan stek, dan jenis tanaman. Faktor lingkungan yang mempengaruhi keberhasilan penyetekan, adalah media perakaran, kelembaban, suhu, intensitas cahaya dan teknik penyetekan (Hartmann et al., 1997). Akinyele (2010) menyatakan bahwa hormon tumbuh dan media perakaran merupakan faktor penting yang mempengaruhi efektifitas pengakaran stek.
Tidak terbentuknya perakaran terkait dengan mekanisme pembentukan akar dalam penyetekan dikendalikan oleh sejumlah faktor yang saling berinteraksi yaitu hara (makro, mikro, karbohidrat, dan air), lingkungan (sinar, suhu dan oksigen), bahan stek (umur jaringan, umur fisiologi, juveniliti, dan tingkat differensiasi) yang semuanya dalam suatu mekanisme yang kompleks dan saling mempengaruhi (Hartmann et al., 1995; Hassanein, 2013). Jika ada salah satu faktor yang membatasi maka seluruh proses pembentukan akar mungkin akan terhambat (Economou \& Read, 1986). Kemampuan pembentukan akar stek sangat dipengaruhi oleh kandungan karbohidrat dan keseimbangan hormon (auksin) yang tercermin pada nisbah $\mathrm{C}$ dan N (Salisbury \& Ross, 1992; Zhang et al., 2013).

Hartmann et al. (1997) mengatakan bahwa keberhasilan perbanyakan secara vegetatif melalui setek sangat ditentukan oleh umur bahan setek dan bagian dari bahan setek yang digunakan. Hal yang sama juga disebutkan oleh Rochiman dan Harjadi (1973) bahwa kondisi bahan setek yang digunakan menentukan 
pertumbuhan akar dan tunas pada setek. Setek yang berasal dari batang yang berwarna cokelat kehijauan mengandung kadar karbohidrat dan nitrogen yang rendah yang dapat mengakibatkan setek menjadi kuning dan selanjutnya kering. Sebaliknya, setek yang berasal dari batang yang berwarna hijau muda mengandung kadar karbohidrat rendah dan nitrogen tinggi yang dapat mengakibatkan setek menjadi busuk. Setek yang berasal dari tunas umur 2 bulan menghasilkan persentase tumbuh paling rendah. Hal ini diduga bahan setek masih muda dan mengandung unsur nitrogen yang relatif tinggi. Hal ini sesuai dengan pendapat Weaver (1972) bahwa kemampuan setek untuk membentuk akar dan tunas bervariasi pada setiap tanaman dan hal ini dipengaruhi oleh kondisi fisiologis bahan setek (stock plant) terutama umur bahan setek, jenis bahan setek, bagian batang yang digunakan, teknik perlakuan, dan faktor lingkungan. Menurut Hartmann et al. (1997), terdapat variasi komposisi senyawa kimia pada bahan tanaman (tunas). Komposisi kimia pada tunas sangat dipengaruhi oleh umur tunas. Tunas yang relatif muda mengandung unsur nitrogen yang relatif tinggi dan unsur karbon yang relatif rendah. Semakin bertambah umur tunas, kandungan nitrogennya semakin menurun, sedangkan kandungan karbonnya semakin bertambah, demikian juga terdapat komposisi kimia yang bervariasi mulai dari pangkal sampai ujung tunas. Variasi komposisi tersebut dapat mempengaruhi kemampuan pertumbuhan akar dan tunas pada setek.

Rochiman dan Harjadi (1973) juga mengatakan bahwa komposisi senyawa kimia dipengaruhi oleh jenis dan bagian bahan setek yang digunakan (pangkal, tengah, dan ujung). Bagian setek yang digunakan berkaitan dengan status nutrisi dalam bahan setek, terutama karbohidrat, protein, lipid, nitrogen, enzim, zat pengatur tumbuh, dan rooting cofactor. Komposisi ini dapat mempengaruhi rasio $\mathrm{C} / \mathrm{N}$ dalam bahan setek. Menurut Hartmann et al. (1997), bahan setek dengan rasio kandungan karbohidrat dan nitrogen (rasio $\mathrm{C} / \mathrm{N}$ ) yang tinggi akan menghasilkan akar yang banyak namun dengan tunas yang lemah, sebaliknya rasio $\mathrm{C} / \mathrm{N}$ yang rendah akan menghasilkan akar yang sedikit dan tunas yang kuat. Keseimbangan kadar $\mathrm{C} / \mathrm{N}$ pada bahan setek dapat dilakukan dengan memilih bagian bahan tanaman yang dijadikan setek, terutama bagian pangkal, tengah, dan ujung setek

\section{KESIMPULAN DAN SARAN}

\section{Kesimpulan}

Tanaman sintok dapat dikembangkan dengan stek batang/pucuk. Pada pengamatan 8 MST stek yang masih hidup rata-rata $15,43 \%$ dan perlakuan Media topsoil dengan tanpa pemberian ZPT (MOP0) menghasilkan tanaman stek yang hidup tertinggi yaitu 55, 55\%. Ratarata stek bertunas pada pengamatan 8 MST adalah $2 \%$. Pada umur stek 8 MST, Stek yang bertunas, semua masih belum muncul akar.

\section{Saran}


Perlunya penelitian lanjutan untuk peningkatan stek hidup dan bertunas serta berakar dengan perlakuan hormon dan pengaturan suhu dan kelembaban saat penelitian, dengan memperpanjang waktu penelitian.

\section{DAFTAR PUSTAKA}

Alfira, A., 2014. Uji Aktivitas Antioksidan Ekstrak dan Fraksi Aktif Kulit Batang Sintok (Cinnamomum sintoc Blume). Skripsi. Program Studi Farmasi. Fakultas Kedokteran dan Ilmu Kesehatan. UIN Syarif Hidayatullah Jakarta.

Arifin, Y. F., Pujawati, E. D., Aqla, M. 2011. Budidaya Tabat Barito (Ficus deltoidea JACK) Secara Stump Dengan Variasi Perlakuan Media Tanam dan Pupuk Organik Nasa. Jurnal Hutan Tropis Vol 12 No. 32 Edisi September 2011. ISSN. 1412-4645. Hal 125-131

Danu, Subiakto, A., Putri, Kurniawati K., 2011. Uji Stek Pucuk Damar (Agathis loranthifolia Salisb) pada Berbagai Media dan Zat Pengatur Tumbuh. Jurnal Penelitian Hutan dan Konservasi Alam Vol. 8 No. 3 :245-252.

Economou, A.S. \& Read, P.E. (1980). Effect of benzyladenine pretreatments on shoot proliferation from petunia leaf segments cultured in vitro. Proc Plant Growth Reg Working Group, 7, 96-103.

Gomez. KA dan Gomez AA. 1995. Statistical Procedures for Agricultural Research. John Wiley and Sons.

Hayati, Nurul Liza. 2011. Keberhasilan Pertumbuhan Stek Pucuk Mindi Besar (Melia dubia Cavanilles) terhadap Penggunaan Media dan Zat Pengatur Tumbuah pada Ruang Pengakaran KOFFCO System dan Model Sungkup. Tesis. Sekolah Pascasarjana. Institut Pertanian Bogor.

Hartmann, H.T., Kester. D.E., \& Davies, R.T. (1997). Plant propagation. Principles and practices. Englewood Cliffs, New Yersey: Regent Prentice Hall.
Hassanein, A.M.A. (2013). Factors influencing plantpropagation efficiency via stem Cuttings. Journal of Horticultural Science \& Ornamental Plants, 5(3), 171-176.

Mashudi dan Adinegara,H.A. 2015. Kemampuan tumbuh stek pucuk pulai gading (Alstonia scholaris (1.) r. br.) dari beberapa posisi bahan stek dan model pemotongan stek. Juernal Penelitian Kehutanan Wallacea. Vol.4. Issue 1 (2015) 63-69

Peraturan Menteri Kehutanan No. P.35/Menhut-II/2007 tentang Hasil Hutan Bukan Kayu.

Salisbury, F.B. \& Ross, C.W. (1992). Fisiologi tumbuhan. Jilid 3. Bandung: Penerbit ITB.

Siregar, N., Dharmawati Ferry Djam'ah. 2017. Pengaruh bahan tanaman terhadap keberhasilan setek kranji (Pongamia pinata). . Pros Sem Nas Masy Biobiv Indon. Volume 3 Nomor 1 ISSN: $2407-$ 8050. DOI: $10.13057 / \mathrm{psnmbi} / \mathrm{m} 030105$

Soh, Wuu-Kuang. 2011. Taxonomy revision of Cinnamomum (Lauraceae) in Borneo. Blumea Vol. 56, 241-264. www.ingentaconnect.com/content/nhn/bl umea.

Tak, Silferansti S. 2017. Pembiakan Vegetatif Gasole (Syzygium malaccense (L.) Merr.\&L.M.Perry) dan Simbiosis Fungi Mikoriza Arbuskula Indegenius. Thesis. Sekolah Pascasarjana. Institut Pertanian Bogor. Bogor.

Weaver RJ. 1972. Plant Growth Substances in Agriculture. Freeman, San Fransisco.

Young, J, W,H., Ge, L. Ng. Y. F. and Tan, N. 2009. The Chemical Composition and Biological Properties of Coconut (Cocos nucifera $\mathrm{L}$.) Water. Natural Sciences and Sciences Education Group Nanyang Teknological University, Singapore.

Zhang, J., Chen, S., Liu, R., Jiang, J., Chen, F., \& Fang, W. (2013). Chrysanthemum cutting productivity and rooting ability are improved by grafting. The Scientific World Journal. doi.org/10.1155/2013/286328. 